\title{
MINERAL NUTRITION AND CAFFEINE CONTENT IN COFFEE LEAVES ${ }^{(1)}$
}

\author{
PAULO MAZZAFERA ${ }^{(2)}$
}

\begin{abstract}
The effect of nutrient supply on the caffeine content of coffee (Coffea arabica L.) leaves was investigated. Seeds were germinated in nutrient-agar media lacking N, P, K, Ca, $\mathrm{Mg}, \mathrm{S}, \mathrm{Zn}, \mathrm{B}$ or Mo. The control treatment contained all essential nutrients. The caffeine concentration was determined seven months after seed sowing when the seedlings have 3 to 4 pair of leaves. The omission of $\mathrm{K}$ induced the highest caffeine content in the leaves (24.5 g. $\left.\mathrm{kg}^{-1}\right)$. Caffeine in the control treatment was $21.9 \mathrm{~g} . \mathrm{kg}^{-1}$. Absence of P induced the lowest content, $17.5 \mathrm{~g} \cdot \mathrm{kg}^{-1}$.
\end{abstract}

Index terms: caffeine, Coffea arabica L., mineral nutrition.

\section{RESUMO}

\section{NUTRIÇÃO MINERAL E CONTEÚDO DE CAFEÍNA EM FOLHAS DE CAFÉ}

O efeito do suprimento de nutrientes sobre o conteúdo de cafeína em folhas de café (Coffea arabica L.) foi estudado. Sementes foram germinadas em meios nutrientes de ágar deficientes em N, P, K, Ca, Mg, S, Zn, B ou Mo. O meio-controle continha todos os nutrientes essenciais. A concentração de cafeína foi determinada sete meses após a colocação das sementes nos meios, quando três a quatro pares de folhas haviam sido emitidos. A omissão de $\mathrm{K}$ induziu o maior conteúdo de cafeína nas folhas $\left(24,5 \mathrm{~g}^{\mathrm{kg}} \mathrm{kg}^{-1}\right)$. O conteúdo do alcalóide no tratamento-controle foi de $21,9 \mathrm{~g} \cdot \mathrm{kg}^{-1}$. A ausência de $\mathrm{P}$ induziu maior redução, sendo o conteúdo de 17,5 g.kg ${ }^{-1}$.

Termos de indexação: cafeína, Coffea arabica L., nutrição mineral.

(1) Received for publication in January $27^{\text {th }} 1999$ and approved in July $7^{\text {th }}, 1999$.

(2) Departamento de Fisiologia Vegetal, Instituto de Biologia, Universidade Estadual de Campinas, Caixa Postal 6.109, 13083-970 Campinas (SP). E-mail: pmazza@obelix.unicamp.br 
Caffeine is the most abundant and important alkaloid in coffee. Despite its taste, this alkaloid does not contribute for more than $10 \%$ of the coffee bitterness (Clifford, 1985). The importance of caffeine in the coffee beverage seems to be solely as a stimulant, which is the main reason for its popularity over the centuries.

Although there is thousands of alkaloids in nature some have economic importance because of their physiological effects on humans. Consequently, in view of commercial interests, many studies have been carried out to investigate the factors that would increase their contents in plant tissues and, especially, in cell suspensions. For this purpose different types of stress have been used such as osmotic stress (Godoy-Hernández \& Loyola-Vargas, 1991; Saenz et al., 1993), salt stress (Brachet \& Cosson, 1983) and fungal elicitors (Baumert et al., 1991; GodoyHernández \& Loyola-Vargas, 1991).

Few studies have been carried out with caffeine from coffee plants. Light, in amounts of $400 \mu \mathrm{mol} . \mathrm{m}^{-2} . \mathrm{s}^{-1}$, induced caffeine accumulation in coffee cell suspensions (Frischknecht \& Baumann, 1985). Depending on the size of the cell aggregate, $\mathrm{NaCl}$ can also cause an increase on caffeine contents (Frischknecht \& Baumann, 1985). However, as often to most alkaloids, coffee tissue culture or cell suspension does not accumulate caffeine in amounts comparable to those found in plant tissues (Waller et al., 1983; Frischknecht \& Baumann, 1985). Therefore, it would be interesting to learn more about the environmental and agricultural influences on the caffeine contents of coffee beans and leaves.

A coffee shrub usually takes 2 to 3 years to produce the first fruits, fact that is quite inconvenient for studying the effect of mineral deficiencies on the caffeine contents of beans. Carelli et al. (1989) have demonstrated the difficulties of growing coffee under hydroponics untill a stage were the plant is productive. On the other hand field experiments would not permit full control of nutrient deficiencies. Therefore, it would be interesting to evaluate caffeine variation in leaves as a response to mineral supply in seedlings growing in nutrient-agar medium.

\section{Material and Methods}

Ripe fruits of C. arabica cv. Catuaí Vermelho were collected from a shrub growing outdoors in the experimental plots of Universidade Estadual de Campinas, State of São Paulo, Brazil. Under aseptic conditions, they were surface-sterilized by immersion in $80 \%$ ethanol for $5 \mathrm{~min}$ followed by washing with sterile $\mathrm{H}_{2} \mathrm{O}$ and immersion in commercial $\mathrm{NaOCl}$ solution $(2 \% \mathrm{Cl})$ for $30 \mathrm{~min}$. After extensive washing with sterile $\mathrm{H}_{2} \mathrm{O}$ the fruits were manually depulped and seeds were treated with $0.5 \mathrm{~N} \mathrm{NaOH}$ for $30 \mathrm{~min}$, to remove the adhered mucilage. The fruits were washed 10 times with sterile $\mathrm{H}_{2} \mathrm{O}$ and the excess $\mathrm{H}_{2} \mathrm{O}$ was removed by laying the seeds on sterile paper filter.

Variations of the complete Hoagland solution (Hoagland \& Arnon, 1950) were used to induce deficiencies. Solutions lacking N, K, P, Ca, Mg, S, B, Zn or Mo were prepared with deionized $\mathrm{H}_{2} \mathrm{O}$. As control, a complete Hoagland nutrient-agar was prepared. The nutrient-agar media were prepared by boiling the nutrient solutions containing $1 \%$ agar in a microwave oven. Before the addition of agar and boiling, all nutrient solutions were passed through $0.2 \mu \mathrm{m}$ filters. The nutrient-agar media were distributed in $500 \mathrm{~mL}$ flasks ( $100 \mathrm{~mL}$ per flask) in an aseptic chamber. When $\mathrm{NH}_{4}$ was included, it was added as a filtered solution concentrated 10 times after the agar temperature had dropped to approximately $50^{\circ} \mathrm{C}$.

Three selected seeds were placed in each flask with the flat face down. The flasks were sealed with parafilm and left in a growth chamber (temperature $20-25^{\circ} \mathrm{C}$ and photon flux density of $c a 250 \mu \mathrm{mol} . \mathrm{m}^{-2} \cdot \mathrm{s}^{-1}$ ) until most of the seedlings produced 3 to 4 pair of leaves. Five replicates were prepared for each treatment and control.

For caffeine analyses, the leaves of the three seedlings of each flask were collected and dried at $80^{\circ} \mathrm{C}$. This occurred 210 days after transfer of the seeds to the flasks. The leaves finely ground in a mortar with pestle, extracted and analyzed by reversed-phase high-performance chromatography according to Mazzafera et al. (1994). 


\section{Results and Discussion}

Two months elapsed before the emergence of the radicles. Probably, this long period occurred because the endocarp was not removed (Válio, 1980), and also because of the sterile conditions, which prevented microbial action on this physical barrier. Usually radicle emergence in germinating coffee seeds takes 15 to 20 days under non-sterile conditions.

At harvesting time, the leaves were smaller than usually found on seedlings of the same age growing in greenhouse or nursery. This might have occurred because of the low light intensity of the growth chamber compared to natural day light. On the other hand, the light intensity of the growth chamber $(250 \mu \mathrm{mol}$. $\left.\mathrm{m}^{-2} \cdot \mathrm{s}^{-1}\right)$ might have not interfered with caffeine biosynthesis. Frischknecht \& Baumann (1985) observed that a similar light intensity $\left(400 \mu \mathrm{mol} \cdot \mathrm{m}^{-2} \cdot \mathrm{s}^{-1}\right)$ induced caffeine accumulation in coffee cell suspensions compared to cells grown in the dark.

Except for the leaves of seedlings from the treatment $-\mathrm{N}$, which were slightly chlorotic, no typical visible symptoms of deficiency were observed. This might have happened because there was not enough time for the development of typical deficiency symptoms. Because $\mathrm{N}$ in coffee is required in higher amounts compared to other nutrients (Moraes \& Catani, 1964), it became limiting in the $-\mathrm{N}$ treatment, and leaf chlorosis could be observed in young leaves. The leaves did not differ in dry matter.

The caffeine content found in the leaves (Table 1) was higher than values reported in the literature for C. arabica (Mazzafera \& Magalhães, 1991). However, this would be expected since it has been demonstrated that younger leaves have higher alkaloid contents than older leaves (Frischknecht et al., 1986).

Although statistically similar to the control treatment, omission of $\mathrm{K}$ induced the greatest increase (12\%) of caffeine contents in leaves. Except for Mo, all other nutrient omissions led to lower values than the control. Treatments $-\mathrm{N}$ and $-\mathrm{P}$ showed the lowest contents.
Table 1. Caffeine content in leaves of coffee seedlings grown in nutrient agar media deficient in nutrients

\begin{tabular}{|c|c|c|}
\hline Treatments & Caffeine $^{(1)}$ & $\begin{array}{l}\text { Increase/ } \\
\text { /Decrease }\end{array}$ \\
\hline & g. $\mathrm{kg}^{-1}$ dry weight & $\%$ \\
\hline -K & $24.5 \pm 0.1 \mathrm{a}$ & 112 \\
\hline -Мо .......................... & $22.5 \pm 0.3 \mathrm{ab}$ & 103 \\
\hline Complete (control) .... & $21.9 \pm 0.3 \mathrm{abc}$ & 100 \\
\hline -B & $21.6 \pm 0.5 a-d$ & 98 \\
\hline 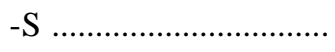 & $20.2 \pm 0.2 \mathrm{bcd}$ & 92 \\
\hline$-Z n$ & $20.0 \pm 0.2 \mathrm{bcd}$ & 91 \\
\hline 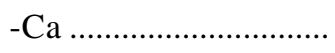 & $18.5 \pm 0.3 \mathrm{bcd}$ & 84 \\
\hline 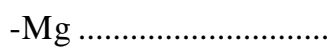 & $18.2 \pm 0.3 \mathrm{~cd}$ & 83 \\
\hline 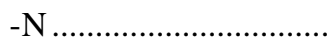 & $17.9 \pm 0.2 \mathrm{~cd}$ & 82 \\
\hline 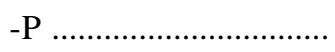 & $17.5 \pm 0.3 d$ & 80 \\
\hline
\end{tabular}

(1) Different letters indicate statistical significance by Duncan test ( $\mathrm{p}$ $\leq 0.05)$.

There is no report in the literature regarding the influence of mineral deficiencies on the caffeine metabolism. Regarding the methyltransferases involved in the caffeine biosynthesis it is not of our knowledge any study indicating that these enzymes are dependent on a specific ion. However, the opposite occurs with the biodegradation route. Caffeine degradation in fruits and leaves of coffee follows the sequence: caffeine $\rightarrow$ theophylline(1,3-dimethylxanthine) $\rightarrow$ 3-methylxanthine $\rightarrow$ xanthine $\rightarrow$ uric acid $\rightarrow$ allantoin $\rightarrow$ allantoic acid $\rightarrow$ urea + glyoxylic acid $\rightarrow \mathrm{NH}_{4}+\mathrm{CO}_{2}$. Urease, responsible for urea degradation, is dependent on nickel (Stebbins \& Polacco, 1995), has very low activity in coffee fruits and leaves (Vitória \& Mazzafera, 1999), and is positioned in the very end of the caffeine catabolism (Suzuki et al., 1992). Vitória \& Mazzafera (1999) observed that the activity of xanthine oxidase in vitro assays with protein extracts from coffee fruits and leaves of $C$. arabica was improved by addition of Mo in the reaction mixture. However, here it was observed that the accumulation of caffeine due to Mo deficiency did not differ from the control treatment. 
Lukaszewski et al. (1992) observed that boric acid inhibited allantoate amidohydrolase in soybean leaves, causing accumulation of allantoic acid. This enzyme is involved in caffeine catabolism (Suzuki et al., 1992). If the opposite is true, B deficiency would cause decrease of allantoate and therefore, in caffeine. However, the alkaloid level in the leaves of -B treatment was similar to the control. At the same time, allantoate amidohydrolase is dependent on manganese, but this nutrient was not tested in the present work.

Since alkaloids are N-containing compounds, low caffeine content might be expected in the plants of $-\mathrm{N}$ treatment. Although there is few exceptions, several reports have shown an increase in alkaloid content due to $\mathrm{N}$ fertilization (Waller \& Nowacki, 1978). On the other hand, the response may vary depending on the nutrient source (nitrate, ammonium or urea) and the alkaloid type.

Regarding other nutrients, $\mathrm{Cu}$ amendments enhanced and $\mathrm{Zn}$ depressed nicotine contents in Nicotiana tabacum (Tso et al., 1973). B, Mo, Mn and Cu amendments caused a decrease on alkaloid contents in Lupinus species (Mironenko, 1965). In most cases, depletion of potassium reduces alkaloid contents in plants (Waller \& Nowacki, 1978). However, in all such cases it is not known the mechanisms leading to alkaloid accumulation.

Recently, Yun et al. (1999) showed that K and $\mathrm{Mg}$ fertilizer application increased caffeine in tea leaves (Camellia sinensis). However, the experiment was carried out in the field in a soil with low $\mathrm{pH}$ and low organic matter, which may have also interfered with the results.

To our knowledge only one investigation reports on the effect of mineral nutrition on caffeine contents of leaves and seeds of coffee (Rodriguez, 1961). The omission of Fe, Mn, B, Zn and Mo was tested throughout one year in three-year old coffee shrubs (C. arabica cv. Bourbon) by spray or soil fertilization associated or not with gypsum or lime application in the soil. Reduction in caffeine contents (3.2\%), although not statistically significant, was observed in the seeds with gypsum omission and an increase (17.5\%) with $\mathrm{Zn}$ omission. The control plants were sprayed with these micronutrients. The author did not report any nutritional deficiency symptoms probably because the experiment was carried out during a short period and also because the nutritional conditions of the soil may have interfered with the results.

It is very likely that these interferences did not occur in the present work. From our data it is not possible to speculate the way each nutrient affected caffeine metabolism. However, it is clear that caffeine contents in coffee is leveled by a balanced mineral nutrition. Considering that the metabolism of caffeine is very similar in fruits and leaves of $C$. arabica (Suzuki \& Waller, 1984; Mazzafera et al., 1994; Ashihara et al., 1996) it is possible that the responses observed here might be observed also in fruits.

\section{References}

ASHIHARA, H.; MONTEIRO, A.M.; MORITZ, T.; GILLIES, F.M. \& CROZIER, A. Catabolism of caffeine and related purine alkaloids in leaves of Coffea arabica L. Planta, Heidelberg, 198: 334-339, 1996.

BAUMERT, A.; MAIER, W.; SCHUMANN, B. \& GROGER, D. Increased accumulation of acridone alkaloids by cell suspension cultures of Ruta graveolens in response to elicitors. Journal of Plant Physiology, Jena, 139:224-228, 1991.

BRACHET, J. \& COSSON, L. Changes in the total alkaloid content of Datura inoxia Mill. subjected to salt stress. Journal of Experimental Botany, Oxford, 37:650-656, 1983.

CARELLI, M.L.C.; FAHL, J.I. \& MAGALHÃES, A.C. Assimilação de nitrato durante o desenvolvimento reprodutivo de plantas de café. Revista Brasileira de Ciência do Solo, Campinas, 13:59-64, 1989.

CLIFFORD, M. N. Chemical and physical aspects of green coffee and coffee products. In: CLIFFORD, M. N. \& WILLSON, K.C., eds. Coffee: botany; biochemistry and production of beans and beverage. Westport, Connecticut, AVI Publishing, 1985. p.305-374. 
FRISCHKNECHT, P.M. \& BAUMANN, T.W. Stress induced formation of purine alkaloids in plant tissue culture of Coffea arabica. Phytochemistry, Oxford, 24:2255-2257, 1985.

FRISCHKNECHT, P.M.; ULMER-DUFEK, J. \& BAUMANN, T.W. Purine alkaloid formation in buds and developing leaflets of Coffea arabica: expression of an optimal defence strategy? Phytochemistry, Oxford, 25:613-616, 1986.

GODOY-HERNÁNDEZ, G. \& LOYOLA-VARGAS, V.M. Effect of fungal homogenate, enzyme inhibitors and osmotic stress on alkaloid content of Catharanthus roseus cell suspension cultures. Plant Cell Reports, Heidelberg, 10:537-540, 1991.

HOAGLAND, D.R. \& ARNON, D.I. The water: culture method for growing plants whithout soil. Berkeley, California Agriculture Experimental Station, 1950.39p. (Circular 347)

LUKASZEWSKI, K.M.; BLEVINS, D.G. \& RANDALL, D.D. Asparagine and boric acid cause allantoate accumulation in soybean leaves inhibiting manganese-dependent allantoate amidohydrolase. Plant Physiology, Bethesda, 99: 1670-1676, 1992.

MAZZAFERA, P.; CROZIER, A. \& MAGALHÃES, A.C. Caffeine metabolism in Coffea arabica and other species of coffee. Phytochemistry, Oxford, 30:3913-3916, 1991.

MAZZAFERA, P.; CROZIER, A. \& SANDBERG, G. Studies on the metabolic control of caffeine turnover in developing endosperms and leaves of Coffea arabica and Coffea dewevrei. Journal of Agricultural and Food Chemistry, Washington, 42:1423, 1994.

MAZZAFERA, P. \& MAGALHÃES, A.C. Cafeína em folhas e sementes de Coffea e Paracoffea. Revista Brasileira de Botânica, São Paulo, 14:157-160, 1991.

MORAES, F.R.P. \& CATANI, R.A. A absorção de elementos minerais pelo fruto do cafeeiro durante sua formação. Bragantia, Campinas, 23:331-336, 1964.

MIRONENKO, A.V. Fiziologya I Biokhimiya Lupina. Minsk, Nauka i Tekhnika, 1965. 325p.

RODRIGUEZ, S.J. The chemical composition of green coffee beans and coffee leaves as related to soil and foliar applications of secondary and minor elements. East Lansing, 1961. 121p. Ph.D. Thesis - Michigan State University, 1961.
SAENZ, L.; SANTAMARÍA, J.M.; VILLANUEVA, M.A.; LOYOLA-VARGAS, V.M. \& OROPEZA, C. Changes in the alkaloid content of plants of Catharanthus roseus L. (Don). as a result of water stress and treatment with abscisic acid. Journal of Plant Physiology, Jena, 142:244-247, 1993.

STEBBINS, N.E. \& POLACCO, J.C. Urease is not essential for ureide degradation in soybean. Plant Physiology, Bethesda, 109: 169-175, 1995.

SUZUKI, T.; ASHIHARA, H. \& WALLER, G.R. Purine and purine alkaloids metabolism in Cammelia and Coffea plants. Phytochemistry, Oxford, 31: 2575-2584, 1992.

SUZUKI, T. \& WALLER, G.R. Biosynthesis and biodegradation of caffeine, theobromine, and theophylline in Coffea arabica L. fruits. Journal of Agricultural and Food Chemistry, Washington, 32:845-848, 1984.

TSO, T.C.; SOROKIN, T.P. \& ENGELHAUPT, M.E. Effects of some rare elements on nicotine content of the tobacco plant. Plant Physiology, Bethesda, 51:805-806, 1973.

VÁLIO, I.F.M. Inhibition of germination of coffee seeds (Coffea arabica L. cv. Mundo Novo) by the endocarp. Journal of Seed Technology, East Lansing, 5:32-39, 1980.

VITÓRIA, A.P. \& MAZZAFERA, P. Xanthine degradation and related enzymes activities in leaves and fruits of two Coffea species differing in caffeine catabolism. Journal of Agricultural and Food Chemistry, Washington, 47:1851-1855, 1999.

WALLER, G.R.; MACVEAN, C.D. \& SUZUKI, T. High production of caffeine and related activities in callus cultures of Coffea arabica L. Plant Cell Reports, Heidelberg, 2:109-112, 1983.

WALLER, G.R. \& NOWACKI, E.K. Alkaloid biology and metabolism in plants. New York, Plenum Press, 1978. 293p.

YUN, R.J; WU, X.; HARDTER, R. \& XUN, W. Effects of potassium and magnesium nutrition on the quality components of different types of tea. Journal of the Science of Food and Agriculture, New York, 79:47-52, 1999. 